\title{
PENERAPAN METODE APPLIED BEHAVIOR ANALYSIS DENGAN MEDIA VISUAL UNTUK MENINGKATKAN AKTIVITAS BELAJAR DAN KETERAMPILAN BERBAHASA
}

\author{
Hotdina Tampubolon \\ Guru SLB-C Karya Tulus, Sumatera Utara \\ dina_tampubolon@gmail.com
}

\begin{abstract}
Abstrak: Tujuan penelitian yang hendak dicapai adalah: (1) untuk mengetahui peningkatan aktivitas belajar siswa autis dalam pembelajaran dengan penerapan metode Applied Behavior Analysis dengan media visual (2) untuk mengetahui peningkatan hasil belajar keterampilan berbahasa siswa autis dengan penerapan metode Applied Behavior Analysis dengan media visual. Penelitian tindakan ini dilaksanakan di SLB-C Karya Tulus yang beralamat di Jln. Namopecawir, Tuntungan II, Kecamatan Pancur Batu, Kabupaten Deli Serdang. Berdasarkan permasalahan yang telah diuraikan dengan mempertimbangkan karakteristik siswa autis, maka metode yang dipilih dalam penelitian ini adalah Penelitian Tindakan Kelas. Sesuai dengan permasalahan dan pendekatan penelitian, maka teknik pengumpulan data yang digunakan dalam penelitian tindakan ini adalah dengan observasi, tes hasil belajar, dan wawancara. Simpulan yang dapat ditarik dari kajian penelitian ini adalah sebagai berikut: (1) dengan menerapkan metode Applied Behavior Analysis yang menggunakan media visual, aktivitas belajar siswa autis pada setiap siklus terus meningkat, terutama pada siklus kedua pembelajaran keempat, persentase aktivitas belajar siswa meningkat cukup tinggi, (2) dengan menerapkan metode Applied Behavior Analysis yang menggunakan media visual, keterampilan berbahasa siswa autis juga mengalami peningkatan yang cukup baik. Sekitar 66,66\% sudah memperoleh keterampilan berkomunikasi dengan kategori baik dan 33,33\% memperoleh tingkat komunikasi dengan sangat baik.
\end{abstract}

Kata Kunci: metode applied behavior analysis, media visual, aktivitas belajar, keterampilan berbahasa

\begin{abstract}
The objectives of the research are: (1) to know the increase of learning activity of autistic student in learning by applying Applied Behavior Analysis method with visual media (2) to know the improvement of learning result of autistic student skill with applied Behavior Analysis method with visual media. This action research is conducted in extraordinary school-C Sincere Work which is located at Jln. Namopecawir, Tuntungan II, Pancur Batu Sub-district, Deli Serdang Regency. Based on the problems that have been described by considering the characteristics of autistic students, then the method chosen in this study is Classroom Action Research. In accordance with the problems and research approaches, the data collection techniques used in this action research is by observation, test results, and interviews. The conclusions that can be drawn from the study study are as follows: (1) by applying Applied Behavior Analysis method using visual media, autistic student learning activity in every cycle continues to increase, especially in the second cycle of fourth learning, the percentage of student learning activity increased quite high, (2) by applying Applied Behavior Analysis method using visual media, students' autistic language skills also experienced a good improvement. Approximately $66.66 \%$ have acquired communication skill with good category and 33,33\% got communication level very well.
\end{abstract}

Keywords: methods of applied behavior analysis, visual media, learning activities, language skills

\section{PENDAHULUAN}

Di SLB-C Karya Tulus Tuntungan. Siswa SLB-C Karya Tulus yang terdiri dari 90 orang, 16,66\% diantaranya selain kecerdasan yang rendah juga mengalami gangguan autisme.
Kondisi seperti ini tentu saja membutuhkan keterampilan khusus dan kesabaran terutama dari guru-guru yang mengajarnya. Kenyataannya, guru-guru masih kesulitan karena terbatasnya pengetahuan tentang 
autisme, juga dipengaruhi oleh faktor tenaga dan waktu. Dari pihak sekolah sudah mencoba mencari metode yang tepat bekerja sama dengan guru-guru dengan memberikan pelayanan yang khusus dengan pembelajaran secara individual dan terapi bicara, namun hasilnya belumlah memuaskan. Guru-guru juga sering merasa kewalahan dalam menghadapi situasi mereka. Maka, untuk menjawab permasalahan ini perlu dicari lagi suatu metode yang efektif yang dapat meningkatkan aktivitas belajar dan komunikasi siswa-siswi yang mengalami autisme.

Jumlah autis di Medan juga mengalami peningkatan, seperti yang dikutip dari Harian Medan (http://www.medanpunya.com), bahwa jumlah anak yang ditemukan terkena autisme akan meningkat. Mulai tahun 1990-an, terjadi lonjakan penderita autis. Namun belum pernah ada survei mengenai data anak autis di Indonesia. Jika diambil statistik prevalensi, maka secara matematis, jumlah anak autis yang lahir di kota Medan khususnya bisa mencapai 250 orang pertahun. Menurut data yang diperoleh dari Pusat Penanganan Autis Terpadu Yayasan Ananda Karsa Mandiri (Yakari), mengatakan penanganan anak penyandang autis mencapai 500 orang sejak berdirinya Yakari tahun 2000. Sedangkan data siswa autis yang ada di sekolah SLB-C Karya Tulus.

Gangguan perkembangan yang dialami anak autis menyebabkan cara mereka belajar tidak sama dengan cara belajar seperti anak lain seusianya dalam banyak hal juga menyangkut soal waktu yang dibutuhkan. Adanya perbedaan tersebut sering juga menjadi hambatan dalam memberikan pendidikan bagi siswa-siswi autis. Di samping biaya yang tidak murah, juga membutuhkan perangkat pendidikan yang berbeda. Apapun resikonya, sesuai dengan amanat dalam undang-undang pokok pendidikan harus tetap menjadi salah satu agenda pendidikan nasional agar anak berkelainan memiliki jiwa kemandirian. Amanat hak atas pendidikan bagi penyandang kelainan atau ketunaan ditetapkan dalam Undang-Undang No. 20 Tahun 2003 tentang Sistem Pendidikan Nasional Pasal 32 disebutkan bahwa pendidikan khusus (Pendidikan Luar Biasa) merupakan pendidikan bagi peserta didik yang memiliki tingkat kesulitan dalam mengikuti proses pembelajaran karena kelainan fisik, emosional, mental, sosial. Autisme merupakan gangguan perkembangan pervasif yang ditandai dengan kegagalan untuk berhubungan dengan orang lain, terbatasnya kemampuan bahasa, perilaku motorik yang terganggu, gangguan intelektual, dan tidak menyukai perubahan dalam lingkungan. Baihaqi dan Sugiarmin (2008: 135) mengemukakan autisme merupakan suatu gangguan yang kompleks. Selain tidak mampu bersosialisasi, anak autis juga tidak dapat mengendalikan emosinya.

Meskipun autisme belum dapat disembuhkan, penelitian selama 30 tahun mendukung pentingnya program penanganan perilaku yang intensif, yang menerapkan prinsip-prinsip belajar untuk mengurangi perilaku yang mengganggu dan meningkatkan keterampilan belajar serta komunikasi pada anak-anak autis. Salah satu pendekatan yang dikembangkan adalah pendekatan perilaku yang didasarkan pada teori operant conditioning yang menempatkan reward dan hukuman secara sistematis diaplikasikan untuk meningkatkan kemampuan anak memperhatikan orang lain, bermain dengan anak lain, mengembangkan keterampilan akademik dan menghilangkan perilaku selfmutilative (Nevid dkk, 2010: 148).

Menurut Sanjaya (2008:132) bahwa salah satu prinsip-prinsip umum penggunaan strategi pembelajaran yang perlu dipahami oleh seorang guru adalah tentang aktivitas. Belajar bukanlah menghafal sejumlah fakta atau informasi. Belajar adalah berbuat, memperoleh pengalaman tertentu sesuai dengan tujuan yang diharapkan. Karena itu, starategi pembelajaran harus dapat mendorong aktivitas siswa. Aktivitas tidak dimaksudkan terbatas pada aktivitas fisik, akan tetapi juga meliputi aktivitas yang bersifat psikis seperti aktivitas mental. Penerimaan pelajaran jika dengan aktivitas siswa itu sendiri, kesan itu tidak akan berlalu begitu saja, tetapi dipikirkan, diolah, kemudian dikeluarkan lagi dalam bentuk yang berbeda atau siswa akan bertanya, mengajukan pendapat, menimbulkan diskusi dengan guru. Bila siswa menjadi partisipasi aktif, maka ia memiliki ilmu/ pengetahuan yang baik.

Menurut Hamzah dan Lamatenggo (2010:122), bahwa pengertian media dalam pembelajaran adalah segala bentuk alat komunikasi yang dapat digunakan untuk menyampaikan informasi dari sumber kepeserta didik dengan tujuan merangsang mereka untuk mengikuti kegiatan pembelajaran dan memberikan penguatan ataupun motivasi. 
Komunikasi memiliki makna luas, yaitu penyampaian energi, gelombang suara tanda di antara tempat, sistem atau organisme. Komunikasi digunakan sebagai proses penyampaian pesan atau pengaruh secara khusus kepada orang lain. Hal ini diperkuat dengan pendapat Morgan ( Danuatmaja, 2003:139) yang mendefenisikan komunikasi sebagai rangsangan yang dibuat suatu organisme yang mengandung makna bagi organisme lain sehingga berpengaruh terhadap perilaku. Komunikasi sebagai suatu proses terdiri dari dua sistem yaitu encoding (memberi rangsangan atau stimulus) dan decoding (menerima dan memberi tanggapan). Berikut ini proses yang terjadi dalam perilaku komunikasi.

Menurut Hurlock (2005:177), jika komunikasi dimaksudkan untuk memenuhi fungsi pertukaran pikiran dan perasaan, maka terdapat dua unsure penting. Pertama, anak harus menggunakan bentuk bahasa yang bermakna bagi orang yang mereka ajak berkomunikasi. Menurut Asrori (2007: 141) perkembangan bahasa adalah kemampuan individu dalam menguasai kosa kata, ucapan, gramatikal, dan etika pengucapannya dalam kurun waktu tertentu sesuai dengan perkembangan umur kronolgisnya. Perbandingan antara umur kronologis dengan kemampuan berbahasa individu akan dapat disimpulkan bagaimana perkembangan bahasa individu yang bersangkutan.

Skinner melihat bahwa hubungan antara stimulus dan respon yang terjadi melalui interaksi dalam lingkungannya, yang kemudian akan menimbulkan perubahan tingkah laku tidaklah sesederhana teori sebelumnya. Skinner melalui teori operant conditioning mampu menjelaskan konsep belajar secara sederhana, namun dapat menunjukkan konsep tentang belajar secara lebih komprehensif (Budiningsih, 2005:24). Teori Skinner menyatakan bahwa setiap kali memperoleh stimulus, individu akan mengadakan respon berdasarkan hubungan stimulus dan respon. Tingkah laku bukanlah sekedar respon terhadap stimulus tetapi suatu tindakan yang disengaja atau yang disebut dengan operant, yang dipengaruhi oleh apa yang terjadi sesudahnya. Dikatakannya bahwa respon yang diberikan oleh seorang siswa tidaklah sesederhana itu. Sebab pada dasarnya stimulus-stimulus yang diberikan kepada seseorang akan saling berinteraksi dan interaksi antara stimulus-stimulus tersebut akan mempengaruhi bentuk respon yang akan ditimbulkan.

Adapun prinsip dasar dari operant conditioning itu sederhana, yaitu: sebuah respon diperkuat, dan karenanya mungkin akan terjadi lagi, ketika respon tersebut diikuti oleh sebuah stimulus yang menguatkan (penguat). Menurut Ormrod (2010: 432) operant conditioning dapat terjadi hanya dalam dua keadaan, yaitu (1) tentu saja pebelajar harus membuat respon, yakni pebelajar harus melakukan sesuatu, (2) penguat harus berdekatan dengan respon pebelajar, yakni penguat seharusnya terjadi ketika, dan hanya ketika, respon yang diinginkan telah terjadi. Misalnya, seorang guru yang memuji para siswanya hanya ketika mereka berperilaku secara pantas membuat penguatan yang berdekatan dengan perilaku yang diinginkan.

Metode yang dikembangkan untuk pendekatan perilaku ini dikenal dengan metode Applied Behavior Analysis. Pendekatan pengajaran dalam metode ini meliputi: keahlian sosial, motorik, verbal, serta keterampilan penalaran. Metode ini menggunakan program penanganan perilaku yang intensif dan terstruktur, dengan banyaknya pemberian instruksi individual. Prinsip dari pelaksanaan metode Applied Behavior Analysis adalah melakukan observasi perilaku dan dorongan atau penguatan positif dalam mengajarkan setiap langkah dari perilaku yang diharapkan. Perilaku seorang anak akan diberi perangsang dengan pemberian hadiah/imbalan tertentu, saat dia berhasil menampilkan setiap langkah yang diperintahkan.

Metode Applied Behavioral Analysis (ABA) dikenal juga dengan sebutan metode Lovaas. Metode ini didasarkan pada teori Operant Conditioning yang dikembangkan oleh Skinner. Sekitar tahun 1979, seorang pakar teori perilaku yang juga sebagai psikologi klinis yang bernama O. Ivar Lovaas dan kawankawan dari UCLA, menawarkan perspektif belajar-kognitif dari autisme (Nevid dkk, 2010: 148). Mereka menyatakan bahwa anak-anak yang autis memiliki defisit perseptual sehingga mereka hanya dapat memproses satu stimulus saja pada waktu tertentu. Karena anak-anak autisme menunjukkan defisit perilaku, fokus utama dari modifikasi perilaku adalah pengembangan perilaku baru. Lovaas menggunakan metode Applied Behavior Analysis dalam upaya membantu anak-anak yang mengalami gangguan perkembangan, lalu 
ia mencoba menggunakan metode ini untuk melatih anak-anak autis di UCLA. Hasilnya sangat menakjubkan. Autisme masa kanakkanak yang semula sangat mustahil disembuhkan, ternyata berhasil ditangani dengan menggunakan metode Applied Behavior Analysis ini, sehingga anak-anak autis dapat memasuki sekolah formal. Dengan keberhasilan ini, Lovaas kemudian mempublikasikan hasilnya, sehingga metode ini lebih dikenal sebagai Metode Lovaas. Menurut Handojo (2009: 3) sampai saat ini belum ada metode lain yang sangat terstruktur dan mudah diukur hasilnya, sebagaimana metode Applied Behavior Analysis atau metode Lovaas.

Metode Applied Behavior Analysis adalah pendekatan ilmiah untuk mengevaluasi perilaku. Metode ini menyediakan informasi ilmiah yang dapat membantu dan memandu pendekatan-pendekatan terapi perilaku yang dapat merujuk pada setiap terapi perilaku yang memanfaatkan berbagai informasi ilmiah tentang perilaku (Priyatna, 2010:106). Prinsip dasar metode Applied Behavior Analysis menurut Handojo (2009:3) merupakan cara pendekatan dan penyampaian materi kepada anak yang harus dilakukan dengan kehangatan, tegas, tanpa kekerasan, adanya prompt, dan apresiasi anak dengan imbalan yang efektif. Metode Applied Behavior Analysis merupakan suatu metode yang banyak digunakan dalam pembelajaran dan terapi bagi anak autisme untuk memberikan rangsangan perkembangan sensorik, motorik, sikap dan perilaku sehingga komunikasi, interaksi sosial, sikap, perilaku dan emosional dapat berkembang.

Dengan melihat permasalahan dan hambatan yang telah diuraikan, penulis tertarik untuk menerapkan metode Applied Behavior Analysis untuk meningkatkan aktivitas belajar dan komunikasi pada siswa-siswi autis di SLBC Karya Tulus Tuntungan. Selama ini pembelajaran yang dilakukan oleh peneliti menggunakan pembelajaran individual dengan metode terapi bicara. Metode terapi bicara ini sebenarnya dikhususkan bagi anak-anak yang tunarungu, sehingga dengan demikian hasil yang diperoleh terutama dalam peningkatan aktivitas belajar dan komunikasi siswa-siswi autis masih relatif minim. Atas dasar permasalahan ini, peneliti ingin menerapkan metode Applied Behavior Analysis dalam pembelajaran anak-anak yang mengalami autisme dengan fokus penelitian pada peningkatan aktivitas belajar dan aspek komunikasi melalui pembelajaran keterampilan berbahasa.

Dalam penerapan metode Applied Behavior Analysis ini, tidak terlepas dari media terutama media visual. Penggunaan media visual dalam pembelajaran berkaitan erat dengan karakteristik siswa autis dan kemampuan peserta didik mengingat informasi. Media visual merupakan alat bantu komunikasi yang mewujudkan komunikasi dari anak, dan dengan media visual ini dapat mempermudah siswa-siswi autis dalam belajar karena pada umumnya mereka sangat tertarik dengan apa yang dapat dilihat secara nyata.

Dengan media visual ini diharapkan penerapan metode Applied Behavior Analysis semakin efektif dalam mengembangkan aktivitas belajar dan peningkatan komunikasi anak autisme. Sebagaimana yang dijelaskan oleh Hogdon dkk (Ormrod, 2009: 247), siswa yang mengalami gangguan autisme seringkali memiliki keterampilan visual spasial yang kuat namun mengalami kesulitan dalam keterampilan bahasa, karena itu penggunaan bahan ajar visual perlu lebih banyak mendapat perhatian. Media visual dengan menggunakan berbagai objek, gambar, dan foto untuk menyampaikan berbagai gagasan di bidang akademik, atau juga menggunakan semacam isyarat visual untuk menandai dimulainya suatu aktivitas baru.

Rumusan masalah dalam penelitian ini adalah sebagai berikut: (1) bagaimana aktivitas belajar siswa autis dalam pembelajaran dengan penerapan metode Applied Behavior Analysis dengan media visual, (2) bagaimana hasil belajar keterampilan berbahasa siswa autis dengan penerapan metode Applied Behavior Analysis dengan media visual?. Hipotesa dapat dirumuskan sebagai berikut: (1) melalui tindakan pembelajaran dengan penerapan metode Applied Behavior Analysis dengan media visual dapat meningkatkan aktivitas belajar siswa autis, (2) melalui tindakan pembelajaran dengan penerapan metode Applied Behavior Analysis dengan media visual dapat meningkatkan keterampilan berbahasa siswa autis.

\section{METODE}

Penelitian tindakan ini dilaksanakan di SLB-C Karya Tulus yang beralamat di Jln. Namopecawir, Tuntungan II, Kecamatan Pancur Batu, Kabupaten Deli Serdang. Subjek dalam penelitian ini adalah siswa-siswa Autis di 
SLB-C Karya Tulus Tuntungan yang berjumlah 6 (enam) orang, dengan rentang usia 8-10. Pemilihan subjek ini didasarkan pada level dan tingkat kesulitan yang kurang lebih sama pada keenam subjek.

Berdasarkan permasalahan yang telah diuraikan dengan mempertimbangkan karakteristik siswa autis, maka metode yang dipilih dalam penelitian ini adalah adalah Penelitian Tindakan Kelas (PTK) atau biasa disebut dengan Classroom Action Research (CAR). Penelitian tindakan kelas merupakan bentuk penelitian reflektif yang dilakukan oleh guru sendiri yang hasilnya dapat dimanfaatkan sebagai alat untuk pengembangan dan perbaikan pembelajaran. Para peneliti PTK tidak berasumsi bahwa hasil penelitiannya akan menghasilkan teori yang dapat digunakan secara umum (digeneralisasi). Penelitian tindakan hanya terbatas pada kepentingan peneliti sendiri, dengan tujuan agar penelitinya dapat melaksanakan tugas pembelajaran dengan lebih baik.

Suhardjono (2007: 58) mengemukakan bahwa penelitian tindakan kelas adalah penelitian tindakan yang dilakukan di kelas dengan tujuan memperbaiki/meningkatkan mutu praktik pembelajaran. Masih senada, menurut Asrori (2007:6) bahwa penelitian tindakan kelas adalah suatu bentuk penelitian yang bersifat reflektif dengan melakukan tindakan-tindakan tertentu untuk memperbaiki dan meningkatkan praktik pembelajaran di kelas secara lebih berkualitas sehingga siswa dapat memperoleh hasil belajar yang lebih baik. Penelitian tindakan kelas merupakan tindakan reflektif yang dilakukan oleh peneliti dalam meningkatkan dan memperbaiki proses pembelajaran di dalam kelas sehingga siswa dapat memperoleh nilai yang lebih baik.

PTK sebagai penelitian tindakan berbeda dari praktik profesional umum, konsultasi, atau pemecahan masalah sehari-hari. Penelitian tindakan menekankan pada studi ilmiah, dimana peneliti mengkaji permasalahan tersebut secara sistematis dan memastikan intervensi tersebut diinformasikan oleh pertimbangan teoritis. Sebagian besar waktu peneliti dihabiskan untuk pengumpulan, penganalisasian, dan penyajian data pada suatu basis siklus yang berkelanjutan (Emzir, 2007: 237)

Penelitian tindakan kelas ini mengandung empat komponen utama atau disebut juga dengan tahapan, yaitu: perencanaan (plan), tindakan (act), pengamatan (observe), dan refleksi (reflect). Keempat komponen tersebut dilakukan dalam tiap siklus yang direncanakan seperti dalam model yang dikemukakan oleh Kemmis dan Taggart (Hopkins, 1993: 48).

Sesuai dengan permasalahan dan pendekatan penelitian, maka teknik pengumpulan data yang digunakan dalam penelitian tindakan ini adalah dengan observasi, tes hasil belajar siswa, dan wawancara, serta tangkapan dari dokumentasi.

Analisis data merupakan tahapan yang dilakukan setelah pengumpulan data. Menurut Sanjaya (2009: 106) dalam penelitian tindakan kelas, sesuai dengan ciri dan karakteristik serta bentuk hipotesis penelitian tindakan analisis data diarahkan untuk mencari dan menemukan upaya yang dilakukan guru dalam meningkatkan kualitas proses dan hasil belajar siswa. Dengan demikian analisis data dalam penelitian tindakan ini dilakukan dengan analisis kualitatif dan analisis kuantitatif. Analisis data kualitatif digunakan untuk menentukan peningkatan proses belajar khususnya berbagai tindakan yang dilakukan guru. Analisis data kuantitatif digunakan untuk menentukan peningkatan aktivitas dan hasil belajar siswa autis sebagai pengaruh dari setiap tindakan yang dilakukan guru dengan penerapan metode Applied Behavior Analysis $y$ ang telah dilakukan guru.

Indikator keberhasilan penelitian tindakan ini diharapkan bahwa setelah setiap siklus berakhir ada peningkatan aktivitas belajar dan keterampilan berbahasa siswa autis yang ditandai dengan ciri-ciri antara lain : siswasiswa autis menunjukkan sikap antusiasnya dan senang dalam mengikuti kegiatan pelajaran, mempunyai sikap kepatuhan, terlibat aktif dalam interaksi pembelajaran dan kemauan untuk mengikuti instruksi yang diberikan, khususnya yang dapat diamati dan diukur dengan adanya peningkatan aktivitas belajar dan keterampilan berbahasa siswa autis. Tindakan penelitian ini akan dihentikan apabila $70 \%$ siswa dikelas tersebut mendapat nilai $\geq 70$ dan telah menunjukkan keaktifan dalam belajar dengan persentase rata-rata $\geq 80 \%$.

\section{HASIL PENELITIAN}

Untuk memperoleh data mengenai upaya yang dilakukan guru dalam meningkatkan hasil belajar siswa autis dengan menggunakan metode Applied Behavior 
Analysis, maka dilakukan observasi selama kegiatan pembelajaran berlangsung. Untuk mendapatkan hasil observasi yang maksimal kegiatan pembelajaran direkam dan dilakukan observasi ulang. Kegiatan pada tahap pertama meliputi: (a) rencana tindakan, (b) pelaksanaan tindakan, (c) observasi, (d) hasil belajar siswa, dan (e) refleksi.

Rangkuman data penelitian dapat dilihat pada Gambar 1 tentang Grafik perkembangan aktivitas belajar siswa pada siklus I.

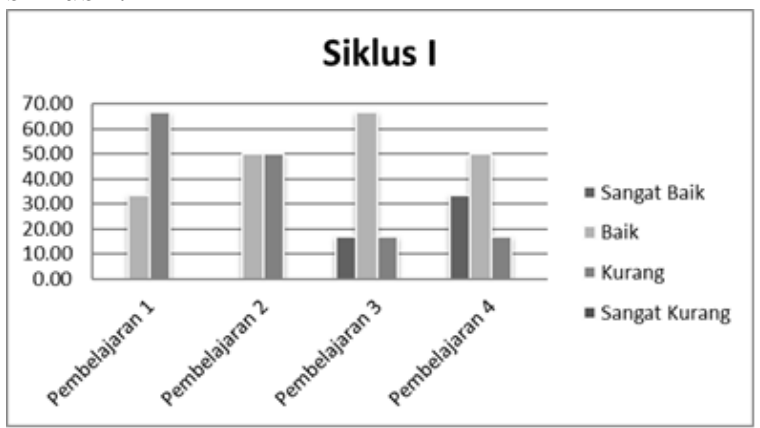

Gambar 1. Grafik Analisis Observasi Aktivitas Belajar Siswa Siklus I

Untuk perkembangan hasil peningkatan keterampilan berbahasa atau berkomunikasi siswa autis dapat dilihat pada Gambar 2 berikut:

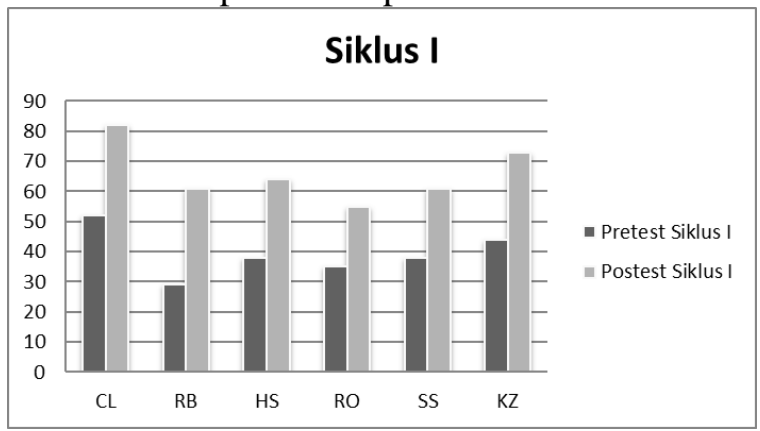

Gambar 2. Grafik Hasil Belajar Keterampilan Berbahasa Siswa Siklus I

Refleksi ini dilakukan secara kolaboratif antara guru (peneliti) dan observer. Hasil refleksi dari peristiwa-peristiwa yang terjadi pada siklus pertama adalah sebagai berikut:

1. Dari hasil observasi pengelolaan pembelajaran pada tindakan siklus I menunjukkan bahwa pertemuan demi pertemuan masih kurang menunjukkan perkembangan yang cukup berarti dengan hasil skor $53,12 \%, 60,93 \%, 67,18 \%$ dan $72,65 \%$. Pada siklus I ini, guru sebagai peneliti belum mampu secara maksimal dalam mengelola dan melaksanakan pembelajaran; masih terlihat kaku, belum mampu menguasai siswa dengan baik, dan ada beberapa indicator yang belum terlaksana dengan maksimal. Dengan demikian pembelajaran dengan menggunakan metode ABA dikatakan belum cukup berhasil. Hasil yang diperoleh belum memuaskan.

2. Berdasarkan hasil observasi yang dilakukan kedua observer terhadap aktivitas belajar siswa pada siklus I selama pembelajaran belum menunjukkan hasil yang diharapkan. Beberapa siswa terlihat masih asik dengan kesukaannya, dengan membuat aktivitasnya sendiri sehingga kurang dapat mengikuti instruksi yang diberikan oleh guru. Hingga pada akhir siklus I yaitu pada pembelajaran yang keempat, 66,66\% siswa sudah memiliki aktivitas belajar dengan baik namun masih terdapat $16,66 \%$ siswa yang memiliki aktivitas belajar dengan kategori kurang. Dengan demikian aktivitas belajar siswa belum cukup memuaskan dan untuk itu masih perlu ditingkatkan.

3. Dari hasil belajar 6 (enam) siswa pada tindakan siklus I terhadap keterampilan berbahasa menunjukkan bahwa nilai ratarata yang diperoleh siswa adalah 66. Siswa yang memperoleh nilai dengan kategori sangat baik ada sekitar $16,66 \%$, siswa yang memperoleh nilai dengan kategori baik ada sekitar 16,66\%, dan masih ditemukan $16,66 \%$ siswa yang memperoleh nilai dengan kategori kurang. Dengan demikian pembelajaran dikatakan belum cukup memuaskan dan masih perlu lagi ditingkatkan.

4. Dari hasil pengamatan kedua observer bahwa ada siswa yang merasa terganggu dengan kehadiran observer dan kamera, sehingga siswa cenderung memperhatikan observer dan tidak memperhatikan guru.

5. Guru telah melakukan tugasnya dengan baik, yaitu melaksanakan rencana pembelajaran sebagaimana mestinya, mulai dari menjelaskan tujuan, menarik perhatian siswa, membimbing siswa dalam melaksanakan pembelajaran sesuai metode Applied Behavior Analysis dan mengadakan evaluasi sesuai dengan indicator yang ada. Guru sudah mencoba memberi perhatian serta motivasi terutama kepada siswa yang mengalami kesulitan dalam merespon. Guru juga mengamati semua kegiatan dalam proses pembelajaran dan juga melakukan penilaian mulai dari proses hingga akhir 
pembelajaran. Namun demikian masih perlu lagi ditingkatkan terutama dengan siswa yang mempunyai perhatian rendah dan sulit untuk berkonsentrasi.

6. Penggunaan media visual sangat membantu siswa untuk lebih mampu memahami tentang materi yang dijelaskan oleh guru dan siswa lebih dapat memberikan perhatian dengan didukung oleh media yang menarik dan tidak membosankan.

7. Sebagian besar siswa menunjukkan rasa tertarik dengan pembelajaran menggunakan metode Applied Behavior Analysis didukung dengan keberadaan media visual.

Dari analisis data yang telah diuraikan,

maka diperoleh beberapa kesimpulan diantaranya, pembelajaran pada siklus I belum dapat dikatakan berhasil karena masih banyak yang perlu diperbaiki dan ditingkatkan baik dari segi proses maupun dari segi hasil. Dengan demikian, diputuskan untuk melanjutkan tindakan ke siklus II dengan revisi sebagai berikut: (a) dengan memperbaiki rencana pelaksanaan pembelajaran tetap dengan menggunakan metode Applied Behavior Analysis (ABA), (b) menciptakan ruangan yang lebih kondusif dengan mengurangi objek-objek dan suara-suara yang menarik perhatian siswa, (c) memberikan kesempatan kepada siswa untuk lebih memperhatikan objek sesuai materi pelajaran, (d) memotivasi siswa dengan memberikan imbalan dengan benda atau kegiatan yang disukai, (e) guru harus lebih memperhatikan siswa yang memiliki kemamuan rendah dan yang sulit untuk konsentrasi, (f) lebih mengaktifkan siswa dalam pembelajaran dengan memberikan tugas atau tanggung jawab dalam membantu guru terutama dalam meniapkan dan menyiman media sehingga siswa termotivasi dan tertarik untuk mengikuti pembelajaran.

Karena masih kurangnya aktivitas belajar dan keterampilan bebahasa siswa pada siklus I maka dilakukan tindakan lanjutan pada siklus II. Kegiatan pada tahap pertama meliputi: (a) rencana tindakan, (b) pelaksanaan tindakan, (c) observasi, (d) hasil belajar siswa, dan (e) refleksi.

Rangkuman data penelitian dapat dilihat pada Gambar 3 tentang Grafik perkembangan aktivitas belajar siswa pada siklus II.

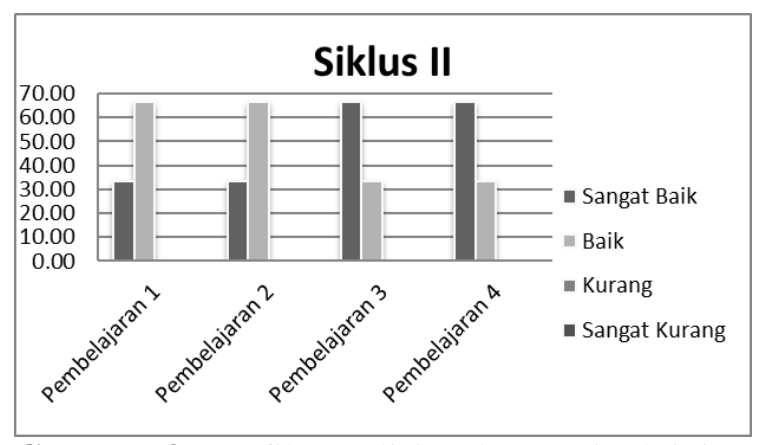

Gambar 3. Grafik Analisis Observasi Aktivitas Belajar Siswa Siklus II

Perkembangan hasil peningkatan keterampilan berbahasa siswa autis ini dapat dilihat pada Grafik berikut (Gambar 4).

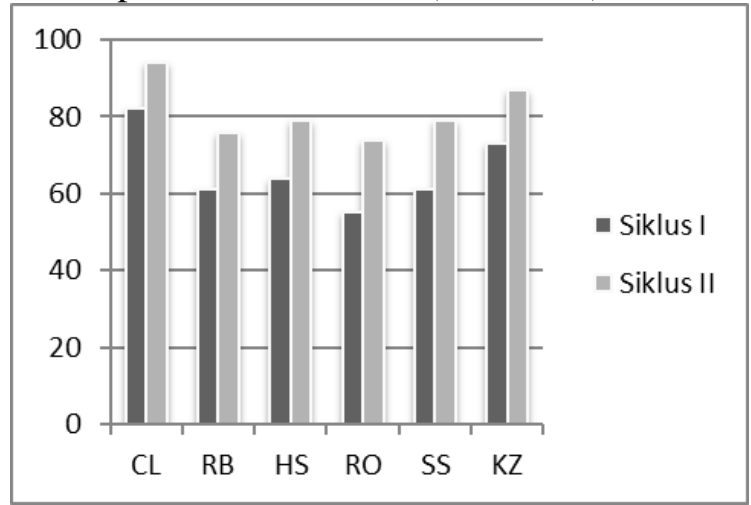

Gambar 4. Grafik Perkembangan

Keterampilan Berbahasa Siswa Siklus II

Hasil refleksi dari peristiwa-peristiwa yang terjadi pada siklus kedua adalah sebagai berikut:

1. Dari hasil evaluasi pada tindakan siklus II (kedua) menunjukkan bahwa pengelolaan pembelajaran belum seluruh aspek dilaksanakan dengan sangat baik karena masih ada beberapa aspek yang perlu ditingkatkan, namun sudah dilaksanakan secara maksimal (baik). Tetapi pada permbelajaran keempat siklus II secara keseluruhan sudah sangat baik dengan persentase nilai rata-rata pada $91,4 \%$ dengan kategori sangat baik. Dengan demikian proses pembelajaran dikatakan telah berhasil, karena sudah mengalami peningkatan dan memenuhi kriteria sukses yang ditetapkan (baik).

2. Berdasarkan lembar observasi aktivitas belajar pada 6 (enam) siswa pada akhir siklus II, 66,66\% siswa memperoleh keberhasilan dengan kategori sangat baik, dan 33,33\% siswa termasuk dalam kategori baik. Persentase rata-rata aktivitas belajar siswa pada siklus II diperoleh $84 \%$, dengan demikian aktivitas belajar siswa autis sudah maksimal dengan mempertimbangkan 
kemampuan dan keterbatasan yang mereka miliki.

3. Berdasarkan analisis hasil tes keterampilan berbahasa pada 6 (enam) siswa pada siklus II menunjukkan 33,33\% hasil belajar siswa dengan kategori sangat baik dan 66,66\% hasil belajar siswa dengan kategori baik. Sedangkan nilai rata-rata diperoleh sekitar 81,5 dengan kategori sangat baik, dimana $100 \%$ siswa yang memperoleh nilai $\geq 70$. Dengan demikian dapat dikatakan bahwa peningkatan keterampilan berbahasa pada siswa autis sudah maksimal sekalipun masih tetap perlu ditingkatkan lagi.

4. Penggunaan media visual (chart dan alat edukatif) sangat membantu pemahaman siswa terhadap materi yang diajarkan dan juga membuat siswa semakin aktif dalam pembelajaran.

5. Siswa menunjukkan tanggung jawab yang baik dalam melaksanakan tugas-tugas yang diberikan oleh guru walaupun terlihat masih ada siswa yang kurang aktif.

Dari analisis data yang telah diuraikan, maka diperoleh hasil bahwa pembelajaran pada siklus kedua sudah mencapai hasil yang maksimal terutama dalam bidang aktivitas belajar dan keterampilan berbahasa. Dengan demikian dapat disimpulkan bahwa pembelajaran siklus kedua tidak perlu dilanjutkan dengan siklus berikutnya. Hal ini dikarenakan hasil tes akhir tindakan siklus kedua sudah memenuhi keriteria yang diharapkan dan ditetapkan.

\section{PEMBAHASAN}

Dari uraian-uraian hasil temuan penelitian tindakan yang telah dideskripsikan dan dianalisis oleh peneliti yang dibantu oleh kedua observer, maka pada pembahasan berikut ini akan dijelaskan bahwa pada prinsipnya penelitian tindakan kelas ini dilakukan adalah selain bertujuan untuk memenuhi tugas akhir pendidikan peneliti juga untuk memperoleh gambaran kualitas pembelajaran terutama pada siswa autis. Pada saat proses penelitian berlangsung terdapat dua hal yang saling keterkaitan dan tidak dapat dipisahkan antara satu dengan yang lainnya sehingga membentuk suatu kesatuan yang utuh, yaitu antara peneliti dan subjek penelitian. Kesuksesan atau keberhasilan dari sebuah penelitian tidak dapat dipisahkan dari kedua faktor tersebut di atas terutama faktor guru atau peneliti itu sendiri, karena dalam penelitian ini guru memiliki peranan yang sangat penting sekali, gurulah yang akan menyajikan dan mengarahkan subjek penelitian.

Dalam penelitian ini guru pengajar memiliki peran ganda, yang pertama berperan sebagai pengajar dan yang kedua berperan sebagai peneliti. Sehingga guru bertanggungjawab penuh terhadap proses penelitian mulai dari tahap persiapan, pelaksanaan penelitian sampai pada akhirnya melakukan pengevaluasian hasil penelitian.

Guru pengajar yang juga bertindak sebagai peneliti tidak menemukan kendalakendala yang sangat berarti dalam melaksanakan, membimbing, dan mengevaluasi proses pembelajaran dengan penerapan metode Applied Behavior Analysis. Hal ini dikuatkan oleh hasil observasi kegiatan dua observer yang juga guru pengajar siswa autis yang menunjukkan bahwa guru mampu menjalankan atau melaksanakan aspek-aspek yang terdapat dalam format observasi dalam pengelolaan pembelajaran dengan penerapan metode Applied Behavior Analysis (lampiran). Atau dengan kata lain guru telah memenuhi keriteria indikator keberhasilan tindakan yang terdapat dalam penelitian ini. Siswa autis yang berjumlah 6 (enam) orang yang dijadikan subjek penelitian juga mampu mengikuti instruksi yang diberikan oleh guru dan mampu menyelesaikan tugas-tugasnya berkaitan dengan materi yang dipelajari dengan baik sesuai dengan format yang telah ditentukan sebelumnya sehingga penelitian ini dapat mencapai suatu keberhasilan yang memuaskan.

Kualitas pembelajaran pada penelitian ini diindikasikan dari penemuan penelitian kegiatan guru selama proses pembelajaran pada siklus pertama yang terdiri dari 4 (empat) pembelajaran, guru belum mampu menerapkan metode Applied Behavior Analysis dengan baik dalam pembelajaran terutama dengan memanfaatkan media visual, namun setelah melakukan refleksi dan revisi disiklus yang pertama, dari hasil penelitian pada tindakan siklus yang kedua diperoleh bahwa ada peningkatan yang baik pada guru dalam melaksanakan pembelajaran. Pada siklus kedua pembelajaran yang keempat diperoleh persentase nilai rata-rata sekitar $91,4 \%$ dengan kategori sangat baik.

Hipotesis pertama yang menyatakan aktivitas belajar siswa autis akan meningkat dengan penerapan metode Applied Behavior Analysis dengan menggunakan media visual, 
dari analisis hasil penelitian menunjukkan bahwa aktivitas siswa mengalami peningkatan dari siklus pertama ke siklus kedua: (1) pada akhir siklus pertama yang terdiri dari 4 (empat) pembelajaran terdapat sekitar $16,66 \%$ siswa yang aktivitas belajarnya masih kurang, 50\% siswa yang memperoleh aktivitas baik, dan $33,33 \%$ siswa dengan aktivitas belajar sangat baik, (2) pada akhir siklus kedua terlihat peningkatan yang cukup baik dimana aktivitas belajar siswa 33,33\% dengan kategori baik dan $66,66 \%$ aktivitas siswa sudah sangat baik. Persentase rata-rata aktivitas belajar siswa Siklus II diperoleh $84 \%$.

Hipotesis kedua menyatakan bahwa komunikasi siswa autis akan mengalami peningkatan bila diterapkan metode Applied Bahavior Analysis dengan menggunakan media visual. Hipotesis ini dapat diuji dengan hasil tes belajar siswa yang menunjukkan peningkatan dari pembelajaran demi pembelajaran terutama pada siklus yang kedua. Tes hasil belajar keterampilan berkomunikasi siswa dimaksudkan untuk menjawab rumusan penelitian tentang ketercapaian peningkatan yang diharapkan. Dari analisis tes hasil belajar keterampilan berbahasa siswa pada akhir tindakan siklus kedua diperoleh nilai rata-rata sekitar 81,5 dengan kategori sangat baik, dengan siswa yang mencapai skor $>80 \%$ adalah 33,33\% dengan kategori sangat baik dan $66,66 \%$ siswa dengan kategori baik. Dari data tersebut dapat disimpulkan bahwa terjadi peningkatan yang sangat memuaskan terhadap keterampilan berkomunikasi siswa autis. Hasil penelitian yang dikemukakan dalam penelitian ini mengalami peningkatan yang sangat baik. Hal ini relevan dengan hasil penelitian yang dikemukan oleh peneliti lain dengan penerapan metode Applied Behavior Analysis pada pokok bahasan yang berbeda.

Dalam implementasinya banyak hal yang kemudian mempengaruhi aktivitas belajar siswa autis dalam kegiatan pembelajaran, perasaan nyaman, senang, benda yang disenangi dan kegiatan yang paling disukai. Namun karena keterbatasan waktu dan biaya maka hal-hal yang sudah diuraikan belum terukur secara maksimal. Akan tetapi dsain pembelajaran yang telah dirancang telah dilaksanakan dengan semaksimal mungkin, dan aktivitas belajar serta keterampilan berkomunikasi siswa sudah mengalami peningkatan yang baik sesuai dengan yang diharapkan. Hal ini berarti bahwa penelitian ini dapat dinilai sudah berhasil

\section{PENUTUP}

Simpulan yang dapat ditarik dari kajian penelitian ini adalah sebagai berikut: (1) Pertama, dengan menerapkan metode Applied Behavior Analysis yang menggunakan media visual, aktivitas belajar siswa autis pada setiap siklus terus meningkat, terutama pada siklus kedua pembelajaran keempat, persentase aktivitas belajar siswa meningkat cukup tinggi dibandingkan dengan persentase aktivitas belajar siswa pada siklus yang pertama dan pada siklus yang kedua persentase aktivitas belajar siswa sudah baik dan sudah dilaksanakan secara maksimal, (2) Kedua, dengan menerapkan metode Applied Behavior Analysis yang menggunakan media visual, keterampilan berbahasa siswa autis juga mengalami peningkatan yang cukup baik. Dari 6 (enam) sampel dalam penelitian ini, sekitar $66,66 \%$ sudah memperoleh keterampilan berkomunikasi dengan kategori baik dan $33,33 \%$ memperoleh tingkat komunikasi dengan sangat baik.

Berdasarkan hasil penelitian tindakan kelas ini, dan beberapa kesimpulan serta implikasi yang diajukan, beberapa saran yang diharapkan berguna bagi perbaikan penerapan metode Applied Behavior Analysis dengan media visual dimasa mendatang adalah sebagai berikut: (1) Pertama, mengingat metode Applied Behavior Analysis dengan media visual sangat berguna dalam upaya membelajarkan siswa dan membuat siswa autis tertarik dan termotivasi untuk mengikuti pembelajaran yang dapat meningkatkan aktivitas belajar dan keterampilan dalam berbahasa, diharapkan penerapan metode Applied Behavior Analysis dengan media visual dapat dipergunakan guru dalam melaksanakan pembelajaran di kelas secara khusus untuk siswa-siswa autis, (2) Kedua, rancangan pembelajaran yang dikembangkan dalam penelitian tindakan kelas ini belum sepenuhnya sempurna, untuk itu bagi guru yang ingin mengimplementasikannya dalam rangka meningkatkan aktivitas belajar dan keterampilan berbahasa siswa autis harus melakukan telaah terlebih dahulu mengenai karakteristik dan memastikan kondisi dilapangan berkaitan dengan sarana yang diperlukan, sehingga akan menghasilkan strategi yang berbeda dan lebih inovatif, dan (3) Ketiga, untuk memperoleh tingkat ketetapan 
dan penerapan metode Applied Behavior Analysis dengan media visual dan penelitian tindakan kelas dalam proses pembelajaran, penelitian tindakan kelas ini sangat perlu dilanjutkan dengan karakteristik siswa yang berbeda sesuai dengan level atau tingkatan kesulitannya dan juga materi yang berbeda. Metode Applied Behavior Analysis perlu dicoba dan diterapkan dalam meningkatkan sosialisasi dan imajinasi dengan pertimbangan kesulitan yang dialami siswa autis secara umum sehingga dengan pendekatan dan penanganan dari berbagai aspek kesulitan siswa autis diharapkan dapat meningkatkan hasil belajar siswa autis yang semakin baik.

\section{DAFTAR PUSTAKA}

Asrori, M.H.2007. Psikologi Pembelajaran. Bandung: Wacana Prima.

Baihaqi dan Sugiarmin. 2008. Memahami dan Membantu Anak ADHD. Bandung: Refika Aditama.

Budiningsih, A.C. 2005. Belajar dan Pembelajaran. Jakarta: Rineka Cipta

Danuatmaja, B. 2003. Terapi Anak Autis di Rumah. Jakarta: Puspa Swara.

Daryanto. 1993. Media Visual untuk Pengajaran Teknik. Bandung: Tarsito.

Depdiknas, 2003. Undang-undang Nomor 20 Tahun 2003 tentang Sistem Pendidikan Nasional. Jakarta: Dirjen PMPTK

Depdiknas. 2002. Kamus Besar Bahasa Indonesia. Jakarta: Balai Pustaka.

Djamarah, S.B dan Zain, A 2000. Strategi Belajar Mengajar. Jakarta: Rineka Cipta.

Elliott, J. 1993. Action Research for Educational Change. Philadelphia: Open University Press.

Gina, G. 2008. Autism and ABA. Jakarta: Gramedia.

Ginanjar. 2000. Kiat Aplikatif Membimbing Anak Autis. Jakarta: Yayasan Mandiga.

Hamalik, O. 1994. Kurikulum dan Pembelajaran. Jakarta: Bhumi Aksara.

Hamalik, O. 2010. Perencanaan Pengajaran Berdasarkan Pendekatan Sistem. Jakarta: Bumi Aksara.

Hamzah, H.B. 2010. Teknologi Komunikasi dan Informasi Pembelajaran. Jakarta: Bumi Aksara.

Handojo, Y. 2009. Autisme pada Anak. Menyiapkan Anak Autis untuk Mandiri dan Masuk Sekolah Reguler dengan Metode ABA Basic. Jakarta: Bhuana Ilmu Populer.
Harian Medan. 2010. Jumlah Anak Autisme di Indonesia Meningkat, [online]: (http://www.medanpunya.com). Diakses Tgl 16 Januari 2012.

Harjanto. 2008. Perencanaan Pengajaran. Jakarta: Rineka Cipta.

Heinich, Robert, Molenda, M. and Russel, J. D. 1995. Instructional Media. New York: Macmillan Publishing Campany

Hopkins, D. 1993. A Teacher's Guide to Classroom Research. Second Edition. Philadelphia: Open University Press.

Hurlock, E. B. 2005. Perkembangan Anak: Jakarta. Erlangga.

Hurlock, E. B. 2009. Psikologi Perkembangan. Suatu Pendekatan Sepanjang Rentang Kehidupan. Jakarta: Erlangga.

Kessick, R. 2011. Autisme dan Pola Makan. Jakarta: Gramedia.

Lasswel, H. D. 1984. The Structure and Function of Communication in Society. In L. Bryson, ed., The Comunication of Ideas. New York: Harper \& Bros.

Maulana, M. 2008. Anak Autis. Mendidik Anak Autis dan Gangguan Mental Lain Menuju Anak Cerdas dan Sehat. Yogyakarta: Kata Hati.

Miarso, Y. 2007. Menyemai Benih Teknologi Pendidikan. Jakarta: Kencana.

Moleong, Lexy. 2001. Metodelogi Penelitian Kualitatif. Bandung: Remaja Rosdakarya.

Nevid, J.S, Rathus, S.A. dan Greene, B. 2010. Psikologi Abnormal. Jilid 2. Jakarta: Erlangga.

Ormrod, J.E. 2009. Psikologi Pendidikan. Membantu Siswa Tumbuh dan Berkembang. Jilid 1. Jakarta: Erlangga.

Priyatna, A. 2010. Amazing Autism. Memahami, Mengasuh, dan Mendidik Anak Autis. Jakarta: Gramedia.

Rogers, E. M. and Kincaid, D. L. 1981. Communication Networks: Toward a New Paradigm for Research. New York: The Free Press.

Sadiman, A.S., Rahardjo, R., Haryono, A. dan Rahadjito, 1990. Media Pendidikan: Pengertian, Pengembangan dan Pemanfaatannya. Jakarta: Rajawali.

Sagala, S. 2011. Konsep dan Makna Pembelajaran. Bandung: Alfabeta.

Sanjaya, W.H. 2008. Strategi Pembelajaran. Berorientasi Standar Proses Pendidikan. Jakarta: Kencana. 
Santrock, J.W. 2002. Life-Span Development. Perkembangan Masa Hidup. Jakarta: Erlangga.

Sardiman, A.M. 2011. Interaksi dan Motivasi Belajar Mengajar. Jakarta: Rajawali Pers.

Severin, W. J. dan Tankard, J. W. 2009. Teori Komunikasi: Sejarah, Metode, \& Terapan di Dalam Media Massa. Jakarta: Kencana.

Slameto. 1995. Belajar dan Faktor-faktor yang Mempengaruhinya. Jakarta: Rineka Cipta.

Stringer, E.T. 1996. Action Research: A Handbook for Practisioner. Thousand Oak London: Sage Publication.

Trianto. 2008. Mendesain Pembelajaran Kontekstual Di Kelas. Jakarta: Cerdas Pustaka Publisher.

Wade, C. dan Tavris, C. 2007. Psikologi. Jakarta: Erlangga

Warsita, B. 2008. Teknologi Pembelajaran. Landasan dan Aplikasi. Jakarta: Rineka Cipta.

Wibawa, B. dan Mukti, F. 2001. Media Pengajaran. Bandung: Maulana.

Yayasan Autisma Indonesia. 1998. Pelatihan Tatalaksana Perilaku (Metode Lovaas) dan COMPIC Pada Penyandang Autisme Gangguan Perkembangan Pada Anak. Jakarta: Graha Sucof. 